\title{
Brisk Attitude and Optimism: Top Workers' Childhood Experiences Forming the Basis of Success at Work
}

\author{
Satu Uusiautti ${ }^{1 *}$ and Kaarina Määttä ${ }^{1}$ \\ ${ }^{1}$ University of Lapland, Finland \\ *Email: satu@uusiautti.fi
}

\begin{abstract}
This study focused on the phenomenon of success at work asking whether it would be possible to find factors from top workers' children and school experiences that would explain their later success. This study was a part of a larger research in which Finnish top workers, employees of the year, who have been selected as successful professionals of their field in Finland were researched. This article focuses on the narrative data collected through qualitative interviews. In this article, their childhood and adolescence experiences were analyzed in order to find out whether successful development could be enhanced already in early phases of life. This study employed the narrative interview method through which top workers were asked to reminisce their childhood and adolescence experiences. What factors have supported their success and how have they coped with adversities in life? According to the results, the most important key to success at work adopted from home was caring upbringing as parents did not set any ambitious goals for success for their children but made the children think about their future and have an optimistic attitude to life. The role of careers counseling at school was also discussed. Analyzing these factors is important if aiming at helping people's chances of finding an occupation they fit and in which they can use their talents. Experiences and events taking place in childhood and adolescence can be crucial, or at least, direct people in a right direction.
\end{abstract}

Key words: success at work, positive development, career, careers counseling.

\section{Introduction}

Is success at work based on childhood and adolescent experiences? What is the influence of parents' expectations in one's career? What is the life span of top workers like? This study focused on top workers, in other words, employees of the year who have been selected as successful professionals of their field in Finland. The study is a part of the larger, two-phased research in which the phenomenon of success at work was analyzed from various points of view (see Uusiautti, 2008; Uusiautti \& Määttä, 2011 a,b,c, 2013) all the way from work motivation and engagement to top workers' strengths and choices in life. However, the influence of childhood and adolescence experiences in relation to adulthood work success has not been widely studied. The idea in this research was to find keys of success from awarded top workers' history.

The theoretical foundation of this study is based on the positive psychology and human flourishing (Seligman, 2002; see also Buss, 2000; Seligman, Steen, Park, \& Peterson, 2005; Duckworth, Steen, \& Seligman, 2005). Likewise, favorable development and growth is one part of the research targets of this emerging positively-toned field (Magnusson \& Mahoney, 2006) and therefore, top workers' childhood memories and experiences makes a natural contribution to the paradigm. It is reasonable to ask whether the life spans of successful and positively-functioning adults differ from other individuals' life spans. And if they do, what are those unique structures that show human strengths and positive 
personhood in the successful individuals' life spans (Magnusson \& Mahoney, 2006)? When considering positive development from the point of view of success at work, it can be asked what factors employees of the year recognize from their life spans and especially from childhood and adolescence as ones enhancing success. This is important if we aim at helping people's chances of finding an occupation they fit and in which they can use their talents. Experiences and events taking place in childhood and adolescence can be crucial, or at least, direct people in a right direction.

Magnusson and Mahoney (2006) have argued that positive development cannot be defined by referring to an individual person but in addition to the person's characteristics, resources, and limits, the cultural, physical, and historical context in which the person lives matters too. Namely, positive development is a holistic process. It means that developmental processes form an entity that affects all levels of the person-environment system. On the other hand, the elements of developmental processes interact. An individual's positive development depends on how well the inner and outer functions of the organism are synchronized. Inner processes are for example mental, biological, and behavioral functions, while other ones cover opportunities, demands, and rules provided by one's environment. Therefore, the developmental process also varies by society and culture (Magnusson \& Mahoney, 2006).

Numerous studies have focused on positive development, and often they take a specific stand or approach to the theme. There are singular studies researching various factors and relationships: for example, studies have found a positive relationship with adolescents' perceived autonomy and self-esteem together with positive relationship with parents has been recognized (Allen et al., 1994). Likewise, parents' socio-economic status predicts not only children's well-being but also intellectual attainment, such as education (e.g., Bradley \& Corwyn, 2002). Furthermore, socioeconomic factors are shown to be related indirectly to children's academic achievement through parents' beliefs and behaviors (DavisKean, 2005). Similar findings have been reported for example regarding parents' role in enhancing their children's acquisition of positive values, attitudes, and behaviors toward sport hobbies (Côté, 1999). However, current approaches to the theme have started to adopt more and more holistic foci concentrating on factors that affect both positive and problem youth development (Catalano et al., 2004).

Success is not just sunshine but necessitates the ability to be flexible, adjust, make compromises and cope with failures and adversities. It is important to consider how the home teaches and supports a child also when he or she does not achieve goals - how difficulties are handled and how they are understood as an inevitable part of life (Määttä \& Uusiautti, 2012ab), how to develop a sense of oneself as an autonomous individual (Eccles, 1999). Therefore the influence of family and upbringing is far from simple when it comes to children's success in later life (see e.g., Aronson Fontes, 2002; Elder et al., 1985; Rowe, 1990). What might be the most crucial for this study is the way people learn to interpret their experiences.

Indeed, top workers do not develop alone but they are surrounded by their families, friends, and relatives. According to Berscheid (2006), human behavior and development should always be understood as the result of living within the network and context of human relationships. It is crucial to find out how these factors enhance the development of self and use of human strengths (Magnusson \& Mahoney, 2006; Caprara \& Cervone, 2006). Indeed, love and attachment that is expressed in relationships that surround us are not about just an affect or a passive inner emotion but active aspiration to help the beloved to grow and be happy (Maijala, Uusiautti, \& Määttä, 2012; Määttä \& Uusiautti, 2012).

\section{The Purpose of This Study}

Probably no one aims at becoming awarded as an Employee of the Year but the road to success at work from the perspective of childhood and adolescence is likely to be something more indefinable and general. Despite these general future hopes and dreams, some people do achieve success at work. Who are they? And how did they become top workers? Did their success start from their childhood or what 
could be the role of their childhood and adolescent experiences? The purpose of this study is to discuss awarded top workers' childhood experiences and what they find especially advancing factors or obstacles in their childhood and adolescence that could explain their favorable growth and development toward success at work.

\section{Research Questions}

This article concentrates on the following question:

1) How do employees of the year describe their childhood and adolescence?

Two sub-questions are set for the main question:

1.1) Which enhancing factors did the rewarded employees of the year consider the most important in their childhood and adolescence? What was their influence and what was their role when remembered as an adult?

1.2) Which obstacles and misjudgments did they consider the most important in their childhood and adolescence? What was their influence and what was their role when remembered as an adult?

\section{Method \\ Data and Analysis}

The original research used a mixed-method approach (see e.g., Creswell, 2002; Teddlie \& Tashakkori, 2003). In the first phase, success at work was studied by focusing on motivation as well as on work engagement. In addition, those characteristics of work considered the most rewarding by participants were studied. The participants had been nominated as "Employee of the Year" between the years 2001 and 2004 in a variety of occupational fields. Altogether, 44 employees were contacted. Of them, sixteen participated by answering questionnaires. Five of them were men, and eleven were women. Seven of those who answered to questionnaires were interviewed during the first phase of the study. Participants were between 29 and 71 years old $($ mean $=49)$.

The research used a mixed-methods approach (see, for example, Teddlie \& Tashakkori, 2003; Creswell, 2002). Data were collected through questionnaires and interviews in 2005. Questionnaires consisted of both quantitative and qualitative parts, on which this article concentrates. The participants were asked to describe their experiences about their work, the significance of their work, their worksatisfaction, challenges in their work, whether their work was rewarding, the most important characteristics of their work, and themselves as workers. The interviews were based on the questionnaires and were qualitative theme interviews, meaning that all the themes in the interviews were decided beforehand but that the order and form of the questions were not.

The second phase, on which this article concentrates, was a narrative study and the data were collected by qualitative interviews in 2007. In the interviews, the participants were asked to review their process of becoming a top worker. Employees of the year that were interviewed $(n=8)$ were nominated between the years 2005 and 2006 (nurse of the year, farmer of the year, police officer of the year $(n=2)$, psychologist of the year, priest of the year $(n=2)$, and artisan of the year). Six of them were men, and two were women. Participants were between 36 and 64 years old $($ mean $=49)$. In the interviews, the participants were asked to discuss the following themes: factors that enhance success, difficulties and obstacles that they had confronted, and choices and decisions they had made during the course of their lives.

The set of narrative data was to complement the first set of data. As the first phase of the research provided descriptions of top workers' current situation and feelings about their work, the narrative method was considered suitable to obtain information about their life stories and development as persons and employees. Altogether, the data triangulation provided a holistic picture of the phenomenon of success at work (see also Uusiautti, 2008; Uusiautti \& Määttä, 2011a,b,c, 2013). 
Narrative research can be defined as research that utilizes or analyses data that is collected via narratives (e.g. biographies) or other such ways (e.g. anthropologists' observational narratives). Thus, a narrative can be either a research object or a means to study a phenomenon (Lieblich, Tuval-Mashiach, $\&$ Zilber, 1998). Narrative research does not focus on objective and generalized facts but on local, personal, and subjective information - this is considered a strength of narrative research because informants' voices of can be heard authentically. Narratives can also be used when analyzing the reasons for actions. In this research, the narrative interview was complemented with characteristics of the theme interview to best serve this research, aiming at thick description of the phenomenon of success at work (see Rubin \& Rubin, 1995).

Polkinghorne (1995) distinguishes the analysis of narratives and narrative analysis. The former means categorizing, for example by types, and metaphors. The latter refers to the composition of a new narrative based on various original narratives. Both of these analysis methods were used in this research: on the one hand, the participants' narratives were categorized by predetermined categories, and on the other hand, a narrative of becoming a top worker was composed.

In this research, an analysis of narratives and narrative analyses were made from the narratives that the participants told in the interviews In this research, the analysis was made using narrative structuring that tries to put together a cohesive narrative of experiences and events during interviews. Furthermore, the analysis typified a category-content-focused approach, with parts of narratives being placed in different categories (Lieblich, Tuval-Mashiac, \& Zilber, 1998).

\section{Limitations of the Research}

When evaluating the reliability of the research, there are a few issues that should be considered. One limitation in this research was the low number of participants. One reason for that certainly is that Finland is a country of 5 million people and therefore the target group (employees of the year) is not big either. Nonetheless, regardless of the low number of participants, the interviews went well and were open and thorough and thus considered valuable.

In this research, participants presented top workers from different occupations. Each of them was nominated as "Employee of the Year" by Finnish labor unions, as most Finnish workers are members of a labor union of their own professional field. These top workers were considered representatives of successful workers and suitable informants for describing their experiences of success at work. Choosing the successful employees was not done by the researchers, ensuring that there was public justification for selecting the participants.

It was interesting to note that the criteria for "Employee of the Year" did not differ much from field to field. The same concerned the age and gender of the top workers. Because of the limited number of participants, it was considered irrelevant to further study the influence of age and gender as no generalizations could be made based on these data. However, as the occupations vary considerably and the data included representatives of women of different ages working in traditional men's occupations and vice versa, we do not have any reason to conclude that the respondents' gender had a significant role. Nevertheless, it is worth pondering how much this actually framed the picture of successful employees that is formed by this research, as winners of "Employee of the Year" awards were, and still are, mainly selected by their own labor unions. For example, making one's occupation renowned can be advantageous for the unions and thus influence someone's selection. Additionally, persons who are more social could be seen as more appealing when being selected as "Employee of the Year". Nonetheless, they constitute a group of successful and excellent workers.

When it comes to the reliability of top workers' childhood memories, it has to be acknowledged that all memory data have their weaknesses. However, the interviews had positively-toned purpose as the participants were already named top workers, people who have achieved success at work, and there- 
fore, reminiscing their childhood was not considered too burdening nor were they expected to share difficult or unspoken experiences or thoughts. The participants were interviewed personally and as personal experiences are not written in documents and archives, research that is based on memories is needed (see e.g., Fingerroos \& Haanpää, 2006, Portelli, 2006). Memory data make it possible to describe top workers' life all the way from their childhood and adolescence. Experiential data can be found in memories told by people themselves. The purpose is not to look for the historical truth as such but the narrated experience refers to the narrator's personal reality. Therefore, a text or story is not supposed to guarantee authentic truth but to find meanings in experiences that the top workers found important enough to tell when contemplating their life spans and paths toward success at work.

\begin{abstract}
Results
The results of the study are introduced in two sections: first, the factors that the top workers' named beneficial to their career development and success at work are discussed. As expected, they could name many of them, and therefore these factors were further categorized into (1) Parents' support and upbringing, (2) Idols, relatives, and friends, and (3) Careers counseling at school. The second results chapter then discusses hardships and obstacles the top workers had faced in their childhood and adolescence.
\end{abstract}

\title{
Childhood events and factors that helped finding one's occupation
}

Success at work can be a result of many factors. Snyder and Lopez (2002) discuss it as a process emphasizing for example the influence of family, school, childhood development, and good work places in the youth. The result section will begin with analyzing parents' influence on top workers' career choices and their attitude to life, successes and hardships, and many characteristics needed in success. Likewise, the role of idols, relatives, and friends as bellwethers are discussed. Third, the significance of careers counseling at school is studied in the light of the top workers' experiences.

\section{Parents' support and upbringing}

Values and educational goals that form the basis of upbringing reflect understanding of the meaning of life, in other words, what people want to achieve or do in order to live a certain kind of life. Home is the most important environment for children because every child is bound to home and under the influence of home environment. Attitudes to life and other people are adopted from home. The influence of home in upbringing is remarkably significant and therefore, the process of becoming a top worker can be analyzed all the way from top workers' childhood and adolescence.

In the interviews, top workers' were asked to reminisce events and factors that have affected their career choices in one way or another and whether their parents had impacted on them. The first reaction was that their parents had not tried to influence. However, for example according to Snyder and Lopez (2002) families do influence on their children's behavior in later life by showing how to explain adversities, how to set goals for the future, and how they strengthen hope in children. Indeed, according to the interviews, parents had merely influenced on top workers' attitude to work than on their actual career choices.

Top workers told that their parents emphasized the importance of having an occupation and earning one's keep in adulthood. Three of the interviewees reported that their parents had some kind of an idea what they might want their child to become and two top workers told that their parents' occupation had directed their career choices too. For example, a farmer had continued their family farm. However, this career choice had not been clear from the beginning. The farmer described the situation as follows:

SU: Was it clear that you will continue the family farm? 
Interviewee no. 2: I don't know. It wasn't any obviousness... Of course, it was always when relatives visited and they would always talk about the young farmer or they would ask something else. - - But it wasn't clear to me... I think that it mattered that I was away for about ten years. It broadened my mind and thoughts and everything surprisingly lot when you look around and see what people do elsewhere in the world. - - My parents haven't ever put pressure on me. Rather they have always asked about my situation. Certainly, these questions were asked more often when my father's retirement got closer.

Another top worker had also had a chance to continue the parents' farm but this top worker noticed already when young that it was not a suitable path. One of the interviewees mentioned quite concrete hope: the top worker's father had wanted his child to become a chemist (in Finland, chemists are entrepreneurs and own pharmacies) but the top worker was not interested in this field. Parents' wish was merely based on chemists' secure and profitable occupation.

One top worker told how studying and having an occupation was strongly encouraged at home. Although parents did not influence on the top worker's career choice, father's occupation had affected childhood and adolescence hobbies and the career choices of the top worker's siblings:

Interviewee no. 3: My father was a musician... Being an artist, he downright demanded that we do music and almost every one of us children had to play the piano or whatever. You have probably heard these stories about compulsory hobbies. We did it, and then some of my siblings, two sisters are cantors and my brother too is a musician.

Other top workers did consider their parents had had much influence on their careers. The most important thing was to find a field that pleases and is interesting and parents did not try to restrict their children. Parents did not put pressure or demands on their children but helped them to think about the future, make their own choices in life, and perceive the possibilities, chances, and well-being life can offer. What is relevant for success is the capability to learn how to get excited, set new goals, and ability to receive positive feedback and thus enhance one's own learning. Furthermore, disappointments are important part of developing self-esteem and mental health (e.g. Desjardins, Zelenti, \& Coplan, 2008). At home, children can learn in a safe environment those means which help to handle disappointments and failures. When necessary, parents can protect their children from the feelings of anxiety and guilt. Successful rearing does not aim at clearing the hardships and obstacles but helping children to learn to confront, tolerate, and conquering the inevitable difficulties (Mcree \& Halpern, 2010).

\section{Idols, relatives, and friends}

Only a few of the interviewees could name a certain idol who had influenced on their career choice. However, three top workers acknowledged someone or some people who had in one way or another helped them finding their occupation. The police told that patriotism in the family had influenced on career dreams. Patriotism was based on respect for relatives having gone to war, and they could be considered the top worker - police's idols. Although the top worker realized that the police's profession was not found only based on this ideology, it still was partly important.

The priest described how the spiritual life had been rooted in the family even if the priest's parents had had temporal occupations, nor were there actual church employees in the family. Nevertheless, the top worker's grandmother had kept Sunday school and the top worker had good memories of it.

These examples show that top workers' stories do not include absolute idols who they would have followed in their lives. Therefore, it is not about admiration with blind worshiping but merely 
these idols' influence is manifested in attitudes, such as patriotism and religiousness. These kinds of positive experiences have directed their career choices later in life.

Friends can also have an influence on careers, and not always the way they affect can be foreseen. Namely, one of the top workers told that the decision of applying for a commercial school was based on a discussion with a friend. They wanted to continue studying together. This is a good example of how powerful an influence adolescent friendships can have, and that the impact of the circle of friends should never be underestimated. In a situation in which choosing a study place is uncertain or difficult, the solution can easily be made with friends.

\section{Careers counseling at school}

The previous sections show that top workers' career choices were not directed by their families but upbringing was directed in enhancing their overall positive attitude to studies and work. Therefore, it was also interesting to find out how school had guided them and whether it had helped them find their occupation.

The significance of school in upbringing becomes especially emphasized if the resources of home and family are not sufficient, or children and adolescent do not get enough information or stimuli from home. Their development can be supported at school, too, by employing their strengths. The purpose of student counseling at school is to support students' personal, social, moral, and occupational development, and therefore it is quite wide-ranging and holistic (Sundvall-Huhtinen, 2007) in nature. In Finnish schools, students have careers counseling, and practical training periods in real work places are important as well.

In the interviews, top workers were asked to describe their experiences of careers counseling at school. Basically, their experiences varied from one extreme to the other. Every one of them remembered their counselor from school, but perceptions of how meaningful the counseling had been, varied considerably.

Three top workers had experiences that could be regarded as positive. One remembered that various occupations were introduced to them, although this top worker went to school when Finnish schools did not yet have separate counselors or practical training periods.

Interviewee no. 5: I think careers counseling was appropriate. I cannot remember which one of the teachers had to do it. - - It provided information about certain occupations and such, so that we could ponder it a bit. So, it was beneficial at that moment.

This top worker did not find the occupation through careers counseling but later, when performing service in the army. However, the positive experience of careers counseling was based on the information provided about different occupations that many youth did not know beforehand.

Another top worker remembered that at school they had to familiarize themselves with occupations that interested them the most. They were asked to write about how to study and get employed in these fields. This top worker told that the current occupation was in mind already that time. Thus, careers counseling helped the top worker know how to acquire that occupation.

The third positive experience differed somewhat from the previous two. Namely, this top worker had sought professional careers counselling after graduating from the general upper secondary education. Careers counseling thus supported the top worker's occupational choice.

Two top workers had quite similar negative experiences of careers counseling at school. Their counselor had told who could apply for vocational school and who could continue to the general upper secondary education and then to higher education. While the first top worker's counselor had not supported the top worker's decision of going to vocational school, the other top worker's counselor had doubtful of the top worker's capability to go to the general upper secondary education. Therefore, ca- 
reers counseling would have directed them in other directions than what they had chosen and became successful in. These two top workers were the youngest of the research participants, and they had also practical training periods at school. Usually, they would go to familiar, neighborhood enterprises to familiarize with the real work life.

Interviewee no. 1: Yes, we had careers counseling at middle school. And I still remember what our counselor of that time told me that your choice is a bad one. I tried to say that I do not agree and tried to give reasons. And the counselor would strongly encourage me to go to the general upper secondary education. I would not. I did not think it would be my thing. I really remember it and we had quite a lot that counseling during the 9 th grade.

Interviewee no. 2: Those careers counseling lessons. Those were about rest and so on. I don't know whether I was just a silly youngster that I didn't understand the idea of counseling or was it because of those counselors. I remember that they all were approaching their retirement age already then, so they were so far away from...

SU: ... yeah, the adolescents' life.

Interviewee no. 2: Yes. --- And when he looked at my records and wondered whether I was really seriously going to the general upper secondary education.

What is the most interesting in the previous example is that counselors do not seem very interested in figuring out what the youth would be interested in. Or this what the top workers remembered. Students were divided into two groups: based on their school grades, they would be suitable to the general upper secondary education or vocational upper secondary education after their compulsory education.

Two top workers reported that careers counseling had not been significant to them at all. They both remembered it but had not personally benefitted from it. In all, it can be concluded that the top workers had not found careers counseling very important and therefore, it cannot be directly called as one of the key factors enhancing their success. However, it could be otherwise.

Why did careers counseling not meet students' needs? One of the reason is probably that top workers who participated in this research went to school in the 1950s-1970s when careers counseling was totally differently organized than it is today. For example, Sundvall-Huhtinen (2007) points out that it was not until the 1970s that the school system started to become more flexible and personal study plans were developed. In addition to changes in the education system, changes in society and especially work life have influenced on the development of careers counseling (Numminen, Jankko, Lyra-Katz, Nyholm, Siniharju \& Svedlin 2002).

The need for counseling and guidance has increased. At the same time, attitudes to the future and occupations have changes considerably: in the 1960-1980s' Finland, the starting point of studying and work was to make the career decision, perform studies, and find stable and secure career, and avoid making mistakes. This was also evident in advice the top workers were given at home by their parents. However, in the 1990s and 2000s, attitudes have changed and emphasis is on having many options, lifelong learning, enjoying life, and learning from mistakes (Sundvall-Huhtinen 2007). The changes in the worldview, living the insecure times, and demand on constant updating and learning at work necessitate efficient guidance that support occupational development.

Top workers mentioned also other, separate factors that they thought that enhanced their careers. One talked about having a year-off between studies after compulsory school. This top worker did not know what would be suitable occupation. During that particular year, the top worker worked in a re- 
tirement home for eight months and familiarized with nursing. Although the top worker did not apply for nursing education straight after that, the top worker realized later that positive work experiences from the retirement home would show the way. Eventually, the top worker studied and graduated as a nurse and has worked as one ever since.

\section{Hardships and obstacles}

Top workers were also asked to describe what kinds of hardships they had faced in their lives and that they considered having affect to their careers. Some specific events were mentioned. For example, the police had not gotten in the cadet school which had been very disappointing. However, this top worker had found the police's profession and applied to police school, got in, and this is how a fine career as a police got started. The setback turned into an advantage, as the plan B became a success story.

Various kinds of career-related hardships could be merely called side-tracks. This is because also top workers were clueless youngsters and trying to find their own paths. One of this kinds of sidetracks happened to two top workers who acquired education but later realized that the field was wrong and did not feel suitable. Stories of side-tracks teach that the right occupation is not always found just like that without going astray. As a matter of fact, wrong choices can even considered strengthening the positive feeling when finding the right path because then one has experiences to compare the new situations with.

Every top worker had had turning points in which they had to decide where to go next. For example, two top workers had the chance of continuing their parents' farm but only one of them eventually did. Both of them became awarded as Employees of the year. What seems most important is to listen to oneself and choose the direction according to one's own feelings, thoughts, and values. One of the top workers expressed this as follows:

Interviewee no. 6: I do not know about those situations when you have to choose or whether the road will go here or there, will I take this or that. I have been wise enough to think what I really want, what is worth investing in with my abilities and talents. And even if that would be really interesting but not quite what is the most suitable, so I have always discussed these profoundly with myself. When it comes to my occupation, I have certainly been thinking what the best use for my strengths is. Because that will lead to such satisfaction and pleasure that cannot be measured by money or respectability of the work.

The previous data excerpt is almost similar to Gardner, Csikszentmihalyi, and Damon's (2001) suggestion according to which people should first think about the mission of the work: what is the nature of the work and why society pays for doing this work, in other words what is the meaning of the work. Second fundamental question relates to the work standards or what kind of performance is expected in the work. Third, people should think about the identity of the work, in other words the moral features and limits that the employee defines and gives reasons.

\section{Conclusions and Recommendations}

According to the results, top workers could not name any particular factors from their childhood that would have been the crucial point in finding the right occupation. Mostly top workers' memories from childhood related to their early adolescence or adolescence (see e.g., Eccles, 1999). Instead, the phenomenon of success at work could be seen as a sum of many factors. However, one important notion can be raised from their childhood. That is the attitude toward education, work, and life in general that was adopted from home. Although top workers' parents did not make the career decisions for their children, they had encouraged them to educate themselves, work hard, and have a positive attitude to- 
ward the future. Indeed, it has been shown that childhood experiences do matter in later development and success in later life (e.g., Hawkins et al., 2005; Larson, 2000).

How to support the success then? Already twenty years ago Arnold, Robertson, and Cooper (1993) emphasized that awareness of one's own strengths and weaknesses, values and points of interest, and knowledge about different occupations are of primary importance for the enhancement of career. According to the results of this study, none of the top workers had found their occupation in careers counseling provided at school, but some of them still appreciated the information about occupations given at counselling.

The latest research in the field of positive psychology has brought the importance of recognizing one's strengths to light (Aspinwall \& Staudinger, 2003). There is not just one road to success at work, and every top worker is an individual. What was common to them was their ability and courage to listen to themselves and be true to themselves. According to Gilligan (2000), childhood-related factors which promote self-directedness or self-efficacy include parents' belief in the child's own sense of control, responsiveness, consistency, warmth and praise, support, and encouragement to the child to engage in his or her environment and surrounding people (see also Sroufe, 2005; Young et al., 2001). Therefore, social skills learned from home can be crucial for the positive development in this sense (see e.g., Decovic \& Janssens, 1992).

The purpose of this study was to illustrate the viewpoint of positive development and strengths with the phenomenon of success at work. It seemed that the most important criterion for success is to find a career that is suitable and in which a person can fulfil oneself. Educators need imagination, courage, and even the ability to take risks so that they can help growing and maturing people test their own limits and abilities (Uusiautti \& Määttä, 2013). Careers counseling can have an important role and should be further researched. Students need information about various occupations and work tasks to be able to evaluate what they find interesting and what they want or can do. Therefore, personal careers counseling also has to help a student recognize his or her abilities and talents, but equally important is to find out which school subjects the student likes the best and what the student likes to do. Questions related to career choice and occupational socialization are surprisingly closely connected with free-time activities (Driver, 1982; Maljojoki 1989; Middleton \& Loughead, 1993).

In addition, students have their own preconceptions of various occupations and thus it is crucial that the expectations in various professions are clarified to students. Abundant practical experiences and examples from real work life cannot be emphasized too much. Furthermore, teachers and counselors should be aware of their prejudices and stereotype conceptions of valuable and not-so-valuable occupations. Top workers who participated in this study went to school four-six decades ago and careers counseling was not as systematic as it is today since the societal interest in adolescent choices emerged in the late 1960s and early 1970s (Petersen, 1988).

It is also worth remembering that regardless of whether a student is a straight-A pupil or just barely passes the school, every student needs careers counseling. Therefore, it is important to highlight the positive experiences of success and being capable - every student has and can have them! It would be interesting to know how the future Employees of the year perceive the role of careers counseling at school.

\section{Implications for Research and Practice}

In all, it became evident that researching the secrets of success from people's childhood and adolescence is not easy. The phenomenon of success does not appear in the same way as failure and therefore, it is not easy to think about reasons for success (Isen, 2001; Uusiautti \& Määttä, 2011). However, for educators, the role of childhood experiences at school and at home appear interesting. For example, Mäkikangas (2007) found out that sensitive and child-centered upbringing was connected with opti-

(C) 2013, European Journal of Educational Research, 2(2), 69-82 
mism in later phases of life (see also Sroufe, 2005). Optimistic attitude described top workers too, and it can be closely related to the overall satisfaction of life. This also includes satisfaction with one's work and career choice.

We, educators, should be ready to meet the challenge of providing children and students with such positive experiences of finding one's own road and being able to fulfil oneself. Lerner et al. (2002) use the word of thriving when discussing the positive development of youth. They emphasize "the five C's of positive youth development: competence, confidence, character, social connection, and caring (or compassion)" (p. 23) that are the benefits of enhancing the positive youth development. Indeed, in addition to the personal benefits of happiness that is achieved through using one's strengths (Seligman, $2002 ; 2011)$, it has also societally beneficial consequences as balanced, satisfied people are also better citizens (Gilpin, 2008).

\section{References}

Allen, J. P., Hauser, S. T., Bell, K. L., \& O'Connor, T. G. (1994). Longitudinal assessment of autonomy and relatedness in adolescent-family interactions as predictors of adolescent egodevelopment and self-esteem. Child Development, 65, 179-194.

Arnold, J., Robertson, I. T., \& Cooper, C. L. (1993). Work psychology. Understanding human behaviour in the workplace. London: Pitman Publishing.

Aronson Fontes, L. (2002). Child discipline and physical abuse in immigrant Latino families: reducing violence and misunderstandings. Journal of Counselling and Development, 80, 31-40.

Aspinwall, L. G., \& Staudinger, U. M. (2003). A psychology of human strength. Washington, DC: American Psychology Association.

Berscheid, E. (2006). Ihmisen suurin vahvuus: toiset ihmiset [Human beings' greatest strength: the other people]. In L. G. Aspinwall \& U. M. Staudinger (Eds.), Ihmisen vahvuuksien psykologia [A psychology of human strengths] (pp. 47-56). Helsinki: Edita.

Bradley, R. H., \& Corwyn, R. F. (2002). Socioeconomic status and child development. Annual Review of Psychology, 53, 371-399.

Buss, D. M. (2000). The evolution of happiness. American Psychologist, 55(1), 15 - 23.

Caprara, G. V., \& Cervone, D. (2006). Persoonallisuus toimivana, itsesäätelevänä järjestelmänä [Personality as functional, self-regulative system]. In L. G. Aspinwall \& U. M. Staudinger (Eds.), Ihmisen vahvuuksien psykologia [A psychology of human strength] (pp. 69-82). Helsinki: Edita.

Catalano, R. F., Berglund, M. L., Ryan, J. A. M., Lonczak, H. S., \& Hawkins, J. D. (2005). Positive youth development in the United States: Research findings on evaluations of positive youth development programs. The ANNALS of the American Academy of Political and Social Science, 591, 98-124. DOI: $10.1177 / 0002716203260102$

Côté, J. (1999). The influence of the family in the development of talent in sport. The Sport Psychologist, 13, 395-417.

Creswell, J. W. (2002). Research design. Qualitative, quantitative, and mixed methods approaches. (2 ${ }^{\text {nd }}$ ed.) Thousand Oaks, CA: Sage.

Davis-Kean, P. E. (2005). The influence of parent education and family income on child achievement: the indirect role of parental expectations and the home environment. Journal of Family Psychology, 19(2), 294-304. DOI: 10.1037/0893-3200.19.2.294

Decovic, M., \& Janssens, J. M. A. M. (1992). Parents' child-rearing style and child's sociometric status. Developmental Psychology, 28(5), 925-932. 
Desjardins, J., Zelenti J. M., \& Coplan, R. J. (2008). An investigation of maternal personality, parenting styles, and subjective well-being. Personality and Individual Differences, 44, 587-597. DOI: 10.1016/paid.2007.09.020

Driver, M. J. (1982). Career concepts - A new approach to career research. In R. Katz (Ed.), Career issues in human resource management (pp. 23-32). New Jersey, NJ: Prentice-Hall.

Duckworth, A. L., Steen, T. A., \& Seligman, M. E. P. (2005). Positive psychology in clinical practice. Annual Review of Clinical Psychology, 1, 629-651.

Eccles, J. S. (1999). The development of children ages 6 to 14. The Future of Children, 9(2), 30-44.

Elder, Jr. G. H., van Nguyen, T., \& Caspi, A. (1985). Linking family hardship to children's lives. Child Development, 56(2), 361-375.

Fingerroos, O., \& Haanpää, R., (2006). Muistietotutkimuksen ydinkysymyksiä [Core questions of memory research]. In O. Fingerroos, R. Haanpää, A. Heimo, \& U.-M. Peltonen (Eds.), Muistitietotutkimus. Metodologisia kysymyksiä [Memoirs research. Methodogical questions] (pp. 25-48). Helsinki: Finnish Literature Association.

Gardner, H., Csikszentmihalyi, M., \& Damon, W. (2001). Good work. When excellence and ethics meet. New York, NY: Basic Books.

Gilligan, R. (2000). Adversity, resilience and young people: the protective value of positive school and spare time experiences. Children \& Society, 14, 37-47.

Gilpin, J. M. (2008). Teaching happiness. The role of positive psychology in the classroom. Pell Scholars and Senior Theses, 12, 1-23.

Hawkins, J. D., Kosterman, R., Catalano, R. F., Hill, K. G., \& Abbott, R. D. (2005). Promoting positive adult functioning through social development intervention in childhood. Long-term effects from the Seattle Social Development Project. Archives of Pediatric \& Adolescent Medicine, 159, 2531.

Isen, A. M. (2001). Some perspectives on positive affect and self-regulation. Psychological Inquiry, $11(3), 184-187$.

Larson, R. W. (2000). Toward a psychology of positive youth development. American Psychologist, 55(1), 170-183. DOI: 10.1037//0003-066X,55.1.170

Lerner, R. M., Brentano, C., Dowling, E. M., \& Anderson, P. M. (2002). Positive youth development: Thriving as the basis of personhood and civil society. New Directions for Youth Development, 95, 11-33.

Lieblich, A., Tuval-Mashiach, R., \& Zilber, T. (1998). Narrative research. Reading, analysis, and interpretation. Thousand Oaks, CA: Sage.

Magnusson, D., \& Mahoney, J. L. (2006). Holistinen lähestymistapa myönteisen kehityksen tutkimuksessa [Holistic approach in research of positive development]. In L. G. Aspinwall \& U. M. Staudinger (Eds.), Ihmisen vahvuuksien psykologia [A psychology of human strengths] (pp. 232-250). Helsinki: Edita.

Maijala, E.-L., Uusiautti, S., \& Määttä, K. (2012). Grandparental love: a challenge or richness? Early Child Development and Care, iFirst, doi: 10.1080/03004430.2012.678491

Maljojoki, P. (1989). Ammatinvalinnanohjauksen taustoja ja kehityspiirteitä Suomessa. Kasvatustieteiden tiedekunnan selosteita 32. Joensuu: Joensuun yliopisto.

McRee, A.-L., \& Halpern, C. (2010). Parenting style and foregone health care as adolescents transition to early adulthood. Journal of Adolescent Health, 46, 10-11. doi: 10.1016/j.adohealth.2009.11.025

Middleton, E. B., \& Loughead, T. A. (1993). Parental influence on career development: An integrative framework for adolescent career counseling. Journal of Career Development, 19(3), 161-173. 
Mäkikangas, A. (2007). Personality, well-being and job-resources. From Negative Paradigm towards Positive Psychology. Jyväskylä: University of Jyväskylä.

Määttä, K., \& Uusiautti, S. (2012a). Parental love -Irreplaceable for children's well-being. Global Journal of Human Social Sciences, 12(10), 1-8

Määttä, K., \& Uusiautti, S. (2012b). Pedagogical authority and pedagogical love - connected or incompatible? International Journal of Whole Schooling, 8(1), 21-39.

Määttä, K., \& Uusiautti, S. (2012). Mission impossible? A scientific comparison between the overlapping and diverging phenomena of friendship and love. International Journal of Asian Social Sciences, 2(4), 530-543.

Numminen, U., Jankko, T., Lyra-Katz, A., Nyholm, N., Siniharju, M., \& Svedlin, R. (2002). Opintoohjauksen tila 2002. Opinto-ohjauksen arviointi perusopetuksessa, lukiossa ja ammatillisessa koulutuksessa sekä koulutuksen siirtymävaiheissa [State of student counseling 2002. Evaluation of counseling in basic education, general and vocational upper secondary education]. Helsinki: National Board of Education.

Petersen, A. C. (1988). Adolescent development. Annual Review of Psychology, 39, 583-607.

Polkinghorne, D. E. (1995). Narrative configuration in qualitative analysis. Qualitative Studies in Education, 8(1), 5-23.

Portelli, A. (2006). Mikä tekee muistitietotutkimuksesta erityisen? [What makes memoirs research special?] In O. Fingeroos, R. Haanpää, A. Heimo, \& U.-M. Peltonen (Eds.), Muistitietotutkimus. Metodologisia kysymyksiä [Memoirs research. Methodologival questions] (pp. 49-64). Helsinki: Finnish Literature Association.

Rubin, H. J., \& Rubin, I. S. (1995). Qualitative interviewing. The art of hearing data. Thousand Oaks, CA: Sage.

Rowe, D. C. (1990). As the twig is bent? The myth of child-rearing influences on personality development. Journal of Counseling \& Development, 68(6), 606.

Seligman, M. E. P. (2002). Authentic happiness. New York, NY: Free press.

Seligman, M. E. P. (2011). Flourish. A visionary new understanding of happiness and well-being. New York, NY: Free Press.

Seligman, M. E. P., Steen, T. A., Park, N., \& Peterson, C. (2005). Positive psychology progress. Empirical validation of interventions. American Psychologist, 60(5), 410 - 421.

Snyder, C. R., \& Lopez, S. J. (2002). The future of positive psychology. A declaration of independence. In C. R. Snyder \& S. J. Lopez (Eds.), Handbook of positive psychology (pp. 751-767). Oxford: University Pres.

Sroufe, L. A. (2005). Attachment and development: A prospective, longitudinal study from birth to adulthood. Attachment \& Human Development, 7(4), 349 - 367.

Sundvall-Huhtinen, A. (2007). Tulevaisuusorientaation huomioiminen nuoren ohjauksessa [Recognizing the future orientation in guidance of the youth]. In J. Helander (Ed.), Reunamerkintöjä ohjaukseen II - avauksia ja aavistuksia opinto-ohjauksen nykyisyydestä ja tulevaisuudesta [Remarks on guidance II. Thoughts about the present day and future of guidance] (pp. 13-22). Hämeenlinna: Häme University of Applied Sciences.

Teddlie, C., \& Tashakkori, A. (2003). Major issues and controversies in the use of mixed methods in the social and behavioral sciences. In A. Tashakkori \& C. Teddlie (Eds.), Handbook of mixed methods in social \& behavioral research (pp. 3-50). Thousand Oaks, CA: Sage.

Uusiautti, S. (2008). “Tänään teen elämäni parhaan työn” Työmenestys Vuoden Työntekijöiden kertomana [Today I'll work better than ever. Success at work described by employees of the year.] (PhD Diss., University of Lapland, Rovaniemi, Finland.)

Uusiautti, S., \& Määttä, K. (2011a). The process of becoming a top worker. International Education Studies, 4(4), 69-79. doi: 10.5539/ies.v4n4p69 
Uusiautti, S., \& Määttä, K. (2011b). Top workers virtues and strengths. GJES: Education Sciences and Psychology, 2(19), 46-56.

Uusiautti, S., \& Määttä, K. (2011c). What kind of employees become awarded of the Year in Finland? Enterprise and Work Innovation Studies, 6, 53-73.

Uusiautti, S., \& Määttä, K. (2013). Love-based leadership in early childhood education. The Journal of Education Culture and Society, 1, 109-120.

Young, R. A., Valach, L., Ball, J., Paseluikho, M. A., Wong, Y. S., DeVries, R. J., \& McLean, H., Turkel, H. (2001). Career development in adolescence as a family project. Journal of Counseling Psychology, 48(2), 190-202. 